\title{
Exploring service delivery protests in post-apartheid South African municipalities: A literature review
}

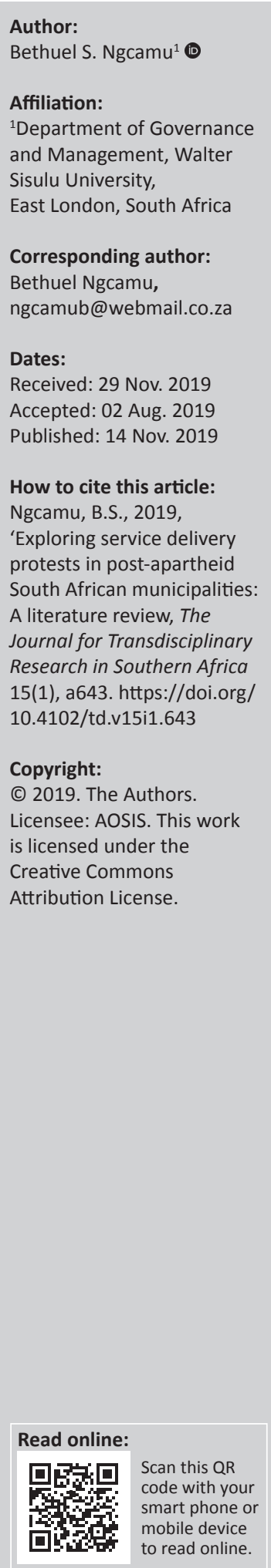

Background: This literature study argues that some studies published in South Africa on service delivery protests at municipal level are unacademic, as they are based on mainly untested, unreliable and unvalidated perceptions.

Aim: This study addresses issues such as how service delivery protests have been conceptualised scientifically by researchers from the perspective of practice, policy and industry; how the conceptualisation has evolved over time; interconnections, if any, between service delivery protests and other elements; dominant dimensions or themes in the scientific literature on service delivery protests; and the impact of lack of public participation on service delivery.

Method: The study adopts a hermeneutic framework, with the literature obtained classified, mapped, critically assessed, themes and arguments developed.

Results: There is a paucity of studies conducted and published between 1994 and 2000 on service delivery protests. Secondly, most studies are narrative analyses of protest events not grounded in any research philosophy, tradition, theory or framework. Lastly, most of the studies are qualitative, with no evidence of reliability and validity being tested and, consequently, acceptability of their findings.

Conclusion: This study is expected to play an important role in shaping government policies and practices and assisting in planning to mitigate service delivery protests and also contribute to the scientific knowledge regarding how scholars perceive service delivery protests. It depicts gaps in the service delivery protests at a municipal level to draw future scholars to conduct empirical studies with an aim to contribute to theory, concept and policy and advise decisionmakers at municipal levels.

Keywords: Civil society; Hermeneutic framework; participation; service delivery protest; South Africa.

\section{Introduction}

The South African government, constituted by the African National Congress (ANC), has been experiencing turbulence manifested in a multiplicity of protests that are worsening at the municipal level where service delivery issues are paramount. An increase in service delivery protests has been correlated with economic retraction, dual pressures of recessionary environment and rising unemployment. The previous statement can be attested to because of the demands and grievances advanced by the unemployed to create employment opportunities or unhappiness with how tenders and jobs are allocated. While the disgruntled citizens may have valid reasons to embark on the service delivery protests, they have been perceived as having a negative impact on government programmes, businesses, investor confidence and jobs. The ongoing service delivery protests can be regarded as a self-defeating strategy to those areas that are more susceptible to them, mostly the municipalities located in the peri(urban) areas. This has been evidenced across the century where the municipal service delivery protests have destroyed several schools that have affected the quality of education (Vuwani in Limpopo province is a typical example). These protests have a detrimental impact on businesses as they are hijacked by criminals who break into and loot shops, forcing businesses to close their doors. Furthermore, business prospects for growth diminish when several days are lost to strikes throughout the country. The service delivery protests do not restore investor confidence, decreasing the reputation of South Africa as an investment destination and having a negative effect on tourism arrivals. In view of the above problems that have been identified, this literature review seeks to determine emerging themes and trends on the published data regarding service delivery protests at a 
municipal level as well as to contribute to theory, policy and practice.

This study attempts to answer the following questions:

- How empirically and academically reliable are the findings of academic and other research on service delivery protests in South Africa?

- What are the reasons for a fluctuating quality of empirical methods and findings?

- How can such problems and challenges be rectified?

A number of commentators have attributed the proliferation of often violent service delivery protests at a municipal level to poor service delivery, low productivity, poor communication, poverty and unemployment, poor participation of communities in decision-making processes and lack of access to information, which has fuelled rumours of favouritism, corruption and mismanagement by officials. Pithouse (2009:251) argues that official discourse from the state, academics and nongovernmental organisations (NGOs), including human rights activists and NGOs, more or less, uniformly describes these protests as 'service delivery protests'. The author posits that the protests are often regarded as targeting local ward councillors who are deemed responsible for rendering municipal services. Several researchers (Alexander 2010; Booysen 2009a; Ngwane 2010; Sinwell et al. 2009; Vally 2009) have suggested that protest action in South Africa is derived from a growing body of research and scholarship, as well as a number of disparate, largely qualitatively based initiatives to collect protest data. Some researchers are of the view that service delivery protests are instigated and led by young people mostly in townships (Matebesi 2011), civil society movements, personally motivated and local groups and immigrants (Akinboade, Mokwena \& Kinfack 2013; Hough 2008). Service delivery protests in South Africa have been characterised by mass meetings, drafting of memoranda, petitions, 'toyi-toying', processions, stay-aways, election boycotts, blockading of roads, construction of barricades, burning of tyres, looting, destruction of buildings, chasing unpopular individuals out of townships, confrontations with the police and forced resignations of elected officials (Akinboade et al. 2013:467; Alexander 2010:26; Sebugwawo 2011).

Scholarly published data on service delivery protests in South Africa are lacking, with the available published literature being anecdotal and informed by popular media rather than theories emanating from the empirical data. This is occurring while a Municipal IQ (2019) has recorded a peak level of service delivery protests in 2018 tallying $24 \%$ more protests than the previous 2014 record holder. The Gauteng province has tended to be the major site for service delivery protests between 2004 and 2008, accounting for 24\% and reaching 36\% in 2017. Conversely, 2018 was totally different, with the Eastern Cape province leading with 20\%, followed by the Western Cape (17\%) and Gauteng province at $16 \%$.

Nyar and Wray (2012) posit that protests occur mostly in urban areas, among groups such as labour, the unemployed and poor, shack dwellers, informal traders, students, local communities and ordinary citizens, whose grievances are related to issues of socio-economic justice. The deep gulf between the state and the urban poor is underlined by the violent response of the police in many instances, resulting in injuries and deaths of protesters as well as innocent bystanders (Beall, Gelb \& Hassim 2005). Researchers such as Akinboade et al. (2013), Alexander (2010), Hough (2008), and Thompson and Nleya (2010) note that service delivery protests are either violent or peaceful, with clear dissatisfaction of local communities about the shortcomings of services rendered to them. Service delivery protests also shed light on a general attitude of disgruntlement with the local government system in South Africa (Mathekga \& Buccus 2006:13). These researchers further postulate that service delivery protests are regarded as a security threat, resulting from elected councillors' failure to provide communities with adequate basic needs, government making empty promises and resistance to government policy on privatisation and private accumulation of wealth by corrupt municipal officials. Thompson and Nleya (2010) posit that inadequate service delivery and lack of accountability, shortage of people with relevant skills to govern, underfunding and the ANC's policy of deployment have exacerbated service delivery protests.

This study provides an in-depth analysis of published literature in databases on dimensions and relationships implicated in violent service delivery protests. Specifically, the study addresses issues such as how service delivery protests have been conceptualised scientifically by researchers from the perspective of theory, concept, policy and practice; how the conceptualisation has evolved over time; interconnections, if any, between service delivery protests and other elements; dominant dimensions or themes in the scientific literature on service delivery protests; and the impact of lack of public participation in service delivery at a municipal level.

This article is divided into seven sections: research methodology context of current protests in South Africa, legislative and policy framework governing protests, analysis of public protests between 1994 and 1999, statistical analysis of service delivery protests and scholarly published literature between 2000 and 2019 on service delivery protests. The article draws conclusions, makes recommendations and provides suggestions for future researchers on the basis of the limitations of the study.

\section{Research methodology}

This article draws a literature review performed by the author for the service delivery protests in South Africa that critically examined peer-reviewed journal articles, book chapters, government reports and theses on service delivery protests in the South African municipality level. The study's research design was a structured review of the South African published work up to 2019. The author consulted a library team to devise an overall search strategy and specific terms (such as the service delivery protests in South Africa) to 
review publications across databases, including SABINET (Southern African Bibliographic Information Network), Google Scholar, IBSS (International Bibliography of the Social Sciences) and IREC (inclusive Research Education Community). The search engine was an iterative process with terms progressively refined to increase the relevance of results. Two academics in the Social Sciences discipline were used to appraise the initial results through a review of abstracts. Abstracts were filtered for their relevance for the objectives of the review. The abstracts were reviewed for quality, citation of the journal articles, reliable empirical base and/or being theoretically sound. A total of 26 quality journal articles were returned initially, which were used in this study. The journal articles espoused some limitations on the impact of service delivery protests which were supplemented by reviewed book chapters and government reports. The researcher's purpose was to download articles that have focussed on the conceptualisation of the service delivery protests, how these have evolved dominant into themes, and the impact of public participation in service delivery protests. However, the majority of the journal articles were generic, not grounded in any theoretical and conceptual frameworks, and mostly qualitative, with very few quantitative research studies found.

\section{Context of current protests}

Published academic literature on service delivery protests is scant, with many authors focussing on causes of protests in articles published in journals such as the International Journal of Social Economics, Journal of South African Studies, Journal of Public Administration and Africanus. South Africa has been described as the protest capital of the world, with diverse triggers of protests, including unhappiness of residents with re-demarcation of wards or municipalities to other areas without proper consultation by government, which has led to burning of public institutions such as schools (e.g. the case of Vuwani in Limpopo). Furthermore, hashtags such as FeesMustFall, commissioned by university students fighting for free education, ZumaMustFall, coordinated by the civil society Save South Africa Campaign, femicide and sexual abuse of women and young girls by religious leaders have exacerbated and changed the nature of protests in South Africa. Moreover, disillusionment and unhappiness with the leadership of the country under President Zuma, which is characterised by political patronage, factionalism, votebuying and gate-keeping, have exacerbated the situation, with the interest of the country subordinated to the interests of a few. Finally, the major cabinet reshuffle on 30 April 2017 negatively affected economic conditions, leading to the country being downgraded by two of three ratings agencies. In early April in the same year, Standard and Poor's (S\&P's) Global Ratings announced the lowering of foreign currency ratings of seven banks (FirstRand Bank, FirstRand, Nedbank, Investec Bank, Absa Bank, Barclays Africa Group and BNP (Banque Nationale de Paris) Paribas Personal Finance South Africa) from 'BBB-/A-3' to 'BB/B' (junk status) out of concern for weakening standards of governance and public finances, followed by a similar downgrading by Fitch, from
'BB+' to 'BBB'. This has ignited a new round of mass protests against what is perceived as mushrooming of the phenomenon of state capture.

\section{Legislative and policy framework governing public protests}

The legislative and policy framework governing public protests in South Africa consists of several instruments, which are briefly outlined here. Chapter 2 of the 1996 Constitution is a Bill of Rights, which outlines various rights citizens are entitled to and which the state is enjoined to respect, protect, promote and fulfil. Among them is the right to assemble, demonstrate, picket and petition. Specifically, Section 17 states that ' $[e]$ veryone has the right, peacefully and unarmed, to assemble, to demonstrate, to picket and to present petitions', while Section 18 guarantees the freedom of association: '[e]veryone has the right to freedom of association'. The Labour Relations Act (No. 66 of 1995) guarantees employees' freedom to participate in protest action. Section 64(1) provides for employees to engage in strikes and employers the right to lock employees out provided: (1) the issue has been referred to a council or to the Commission and a certificate stating that the dispute remains unresolved has been issued; or (2) a period of 30 days, or any extension of that period agreed upon between parties to the dispute, has elapsed since the referral was received by the council of the Commission. The act, however, prohibits employees engaged in essential services from participating in protest action. The Labour Relations Policy Framework for the South Africa Public Service (n.d.) acknowledges the right of employees to participate in protest action provided such action is protected in terms of Section 77 of the Labour Relations Act. It is important to note that an employee cannot apply for leave to engage in protest action and the principle of 'no work, no pay' applies to all protesting employees. Equally important is the fact that employees engaged in essential services are prohibited from engaging in protest as such protest is unprotected.

The Regulation of Gatherings Act 205 of 1993 (amended by the Safety Matters Rationalisation Act 90 of 1996 and Dangerous Weapons Act 15 of 2013) regulates the holding of public gatherings and demonstrations at certain places. The Act is premised on the right to protest:

Every person has the right to assemble with others and to express his views on any matter freely in public and to enjoy the protection of the State while doing so. (p. 1)

The Ministry of Police's Policy and Guidelines: Policing of Public Protests, Gatherings and Major Events (2011, p. 5) seeks to ensure that the policing of public protests and gatherings is consistent with the constitutional rights of all persons, demands of effective and peaceful crowd control, an approach that does not have negative impact and promote tension between the police and the community, and an approach that does not promote the violence it seeks to control in public protests. The purpose of the South African Police Service (SAPS) Standing 
Order (General) No 262 on Crowd Management during gatherings and demonstrations is to regulate crowd management during gatherings and demonstrations in accordance with the democratic principles of the Constitution and acceptable international standards. It states that the use of force must be avoided at all costs and members deployed for the operation must exercise the highest degree of tolerance.

\section{Service delivery historical context}

The pre-Mandela era has been prone to an array of mass protests and Defiance Campaigns with some being sporadic and most being coordinated by civil society groups. Historically there has been a diversified array of mass protests, such as the two Defiance Campaigns in 1952 and 1989, the UDF (United Democratic Front) and Inkatha separate protests in KZN (KwaZul-Natal) and occasionally in Gauteng, as well as the PAC (Pan Africanist Congress) Defiance Campaigns that led to the Sharpeville and Langa massacres in 1960 and, of course, the 1976 Soweto student uprisings. These coordinated mass protests had a clear aim in the abolition of the apartheid laws which were central to segregation in terms of race, white supremacy and the oppression of the majority black population.

The violent service delivery protests mostly prevalent at a local level of government have been associated with the results of apartheid, which was central to segregation, with the majority of the people (black people) being marginalised with regard to basic needs including clean drinking water, proper sanitation, electricity, access to health care, formal housing and access to infrastructure. After the apartheid dispensation, the new democratic government led by the ANC inherited an unequal society that confronted them with protest action associated with a perceived lack of basic service delivery and systematic corruption at the level of local government. Breakfast, Bradshaw and Nomarwayi (2019:107) indicated that such unrest was epitomised by the racial segregation of black, mixed race and Indian people, preventing them from participating in socio-economic and political activities as opposed to their white counterparts. According to Kotze and Taylor (2010:198), communities throughout the country have resorted to violent riots, destroying schools, libraries and the houses of underperforming local government councillors. Mananga (2012) is of the opinion that service delivery protests are exacerbated in the informal settlements where poverty and unemployment are high, with a lack of technical and management skills in municipalities (Steyn \& Van Heerden 2011: 167), lack of accountability by local councillors and municipal officials (Alexander 2010:37), corruption, poor financial management and cadre deployment.

Public protests did not feature prominently during President Nelson Mandela's administration (1994-1999). The notable lull in public protests from the tumultuous apartheid era following the inauguration of Mandela as president in 1994 can be attributed to three main factors. Firstly, according to Ngwane (n.d.), the attainment of independence was widely seen as the dawn of a new era for the country and its citizens, which raised expectations that eventually turned into frustration. In the collective euphoria of the new democratic South Africa, the destructive power of mass protest action that had brought down the apartheid regime had no place; protests were seen as an anomaly and vigorously discouraged by the ANC and alliance partners in favour of mobilisation of the masses to support government programmes. Consequently, if there were any protests at all, they were carefully state-managed to be peaceful. Secondly, militant apartheid-era civic society organisations, including the United Democratic Front, were demobilised. Demobilisation of civil society organisations had the effect of weakening opposition to unpopular government policies. Thirdly, the adoption of the pro-poor Reconstruction and Development Programme (RDP), which was aimed at redistributing wealth, was well received as a pacifying measure. However, in 1996, less than 24 months after introduction of the RDP, the Growth, Employment and Redistribution (GEAR) macro-economic policy was adopted, signalling a shift to neoliberalism that prioritised the interests of big businesses above those of poor citizens. The adoption of GEAR had implications for immediate loss of some economic benefits citizens had enjoyed under the apartheid system. The labour movement and some civil society organisations accused the government of 'selling out the people's mandate' (Bond 2000). Cost recovery was an essential part of GEAR, which soon pitted poor citizens against the government. While the shift to GEAR marked a radical change in how government approached delivery of services and generated criticism from the South African Communist Party and Congress of South African Trade Unions, it did not immediately trigger mass protest action mainly because these two powerful organisations' championing workers' and ordinary citizens' rights were in alliance with the ANC, but the grounds were laid for future public protests.

The inauguration of Nelson Mandela saw a rise in landgrabbing and a proliferation of informal settlements within major cities, which eventually became hotspots of protest action. The first Mandela-era public protests, derogatively referred to as 'pop-corn' or 'mushroom' protests, an example being 'Operation Khanyisa' (Ngwane n.d.), were manifestations of dissatisfaction of new community organisations with the provision of municipal services, housing, roads, electricity cut-offs and other services. The protests were sporadic in nature, short-lived, did not constitute a pattern and were 'trivialized, marginalized and demonized' by the government (Ngwane n.d.). Bond and Mayekiso (1996) describe the public protests during the early post-apartheid years as:

... spontaneous demonstrations, marches, boycotts, highway blockades, wildcat strikes, land invasions, inner-city building squats, sit-ins and occupations of factories and government offices, disruptions of neo-apartheid education, protests against (and by) public service providers (including kidnappings) and mutinies by ANC cadres in the integrated defence forces. (p. 40)

The local government system has shown a sign of being overwhelmed (Alexander 2010), which is characterised in the 
phenomenon of recurring and increasing violent mass protests towards local government that have assumed multiple forms such as partitions, marches, demonstrations and violent confrontations (Nyar \& Wray 2012). Most protests have taken the form of carefully planned marches governed by provisions of the Regulation of Gatherings Act (1993), rendering them 'short, invisible and non-threatening as possible' (Ngwane n.d.). In 1997, two events - the introduction of the neoliberal restructuring Igoli 2000 Programme by the Johannesburg City Council and laying off of employees by the University of the Witwatersrand in favour of outsourcing culminated in the eventual formation of the Anti-Privatisation Forum in 2000, which played a key role in public protests during the Mbeki administration.

\section{The frequency, geographical spread and effect or impact of service delivery protests}

According to the Civic Protest Barometer (CPB), the number of civic protests increased in 2009, with the number reaching 204, followed by a stable period in 2014 (with 176 recorded); and declined in 2015 (with 126 recorded) (Chigwata, Donovan \& Powell 2017). Across the eight metropolitan municipalities were Cape Town (17\%), Johannesburg (14\%), eThekwini Municipality (8\%), Tshwane (7\%) and Ekurhuleni (4\%). The categories of violence reported in protests include intimidation (33\%), personal attack (27\%), damage to property (19\%), arson (14\%) and looting (7\%), while the grievances cited between 2012 and 2016 reported in the popular media include municipal services $(58 \%)$, party political $(15 \%)$, governance $(14 \%)$ and socio-economic challenges (12\%) (Chigwata et al. 2017).

Karen Heese, an economist at Municipal IQ (2016), argues that:

... it is a welcome sign of $[a]$ well-functioning democracy that saw service delivery protests retreat in the immediate run-up to elections. These protests may be violent or peaceful, but there is a clear dissatisfaction with the management of a municipality. (p.3).

Municipal IQ's (2014) Municipal Hotspots Monitor shows that since 2004 South African municipalities have been targets of violent protests, with a peak in violence recorded in 2012 (77\%) and the lowest in 2011 (67\%). Kevin Allan (2016) of Municipal IQ notes that Gauteng (30\%) and the Eastern Cape $(22 \%)$ continue to account for the greatest proportion of protest activities in 2016, followed by KwaZulu-Natal (16\%), Western Cape (8\%), North West (4\%), Mpumalanga (65), Limpopo (55) and Northern Cape (4\%).

The Empowerdex Service Delivery Index (CityDex) (2009) shows a somewhat contrary finding that Gauteng was on the top rung on the status index (83.1), but bottom in terms of improvement (47.4\%). The disproportionately high percentage on the service delivery protests in the Eastern Cape tallies the CityDex (2009), which falls short of the national average on all elements of service delivery (formal dwellings, piped water, formal toilets, waste removal, electric lighting, electric waste removal, electric cooking and electric heating). There is a large service delivery gap between urban and rural municipalities. Of particular concern is the low level of service delivery for communities within the former homelands in the Eastern Cape, North West and Limpopo provinces as well in rural areas of KwaZulu-Natal (Empowerdex Service Delivery Index [CityDex 2009]). It can be deduced from the statistics analysed above that the 'service delivery protests' are increasing at a high rate and can be regarded as part of the development, although these findings cannot be considered reliable and valid. Nyar and Wray (2012) are of the opinion that protest actions in South Africa are diverse and multi-faceted, while the absence of reliable and comprehensive data frustrates attempts to interpret protest action and strategies about the implications. These authors further postulate that quantitative data sources on protest action are less common and are not readily available.

\section{Service delivery protests literature review: The South African context}

While Alexander (2010) argues that South Africa has experienced a movement of local protests amounting to a rebellion of the poor, Booysen (2009a:128-129) suggests that service delivery protests continue to be 'grassroots' actions, the triggers increasingly being national-level responsibilities, including housing, land and jobs. Meanwhile, Thompson and Nleya (2010) cite strong similarities linking the Mbeki- and Zuma-era protests, notably in relation to issues raised that are principally central to inadequate service delivery and lack of accountability by local councillors. Bond (2010) identifies the FIFA (Fédération Internationale de Football Association) World Cup (June-July 2010) as the period when the country's poor and working class continued protesting, triggered by anger attributed to commercialisation of municipal services, increasing poverty and inequality in the country's slums (Freedom of Expression Institute and the Centre for Sociological Research 2009). Bond (2010) cites a multiplicity of factors behind service delivery protests, including the link between rising costs of basic needs (clean drinking water, sanitation and electricity) because of the implementation of the neoliberal policies, forced removals of informal settlements, disparities between luxury stadia and impoverished neighbourhoods and the World Cup's gentrification of innercity access by low-income informal traders. This encapsulates the indignity of poverty, and the bucket sanitation system, especially when municipalities are inefficient and the buckets are not emptied, providing community activists with an effective and ready-made weapon of protest, which has been used with substantial effect in protests about poor service delivery (Muller 2007:36). The dynamics of the phenomenon, familiarly known as 'service delivery protest', have generally been understood by the public within the context of local government failures or shortcomings in terms of, for example, community access to water, electricity, sanitation and basic infrastructure (McLennan \& Munslow 2009). 
A desktop analysis performed by Alexander et al. (2018) reported the frequencies and turmoil of the protests which took place between 2005 and 2017. The authors found the rising trend in frequency of community protest to be disorderly, disruptive and violent. Matebesi and Botes (2017) conducted an in-depth analytical study in two areas in the Eastern Cape and the Northern Cape provinces, where in one area protests were mainly about the shortage and quality of houses and in another area, the protest was about getting the mayor to resign. The researchers found that partisan protesters were consequently able to navigate successfully between the party and concerned resident group. An exploratory study performed by Morudu (2017), where a principal component regression method was utilised to assess the relationship between protests and available data at a local municipal level, found that local municipalities can minimise protests by increasing the provision of services in highly concentrated areas and that an emphasis should be on the actual water supply to communities rather than on the number of the water accounts.

An exploratory study was conducted by Mpehle (2012) in different provinces (KZN, Gauteng and North West) between 2009 and 2010 involving 180 consumers of the municipal services to test whether service delivery protests were justifiable in the democratic South Africa. The author found that the consumers of the municipal services were dissatisfied with the deployment of unskilled, unqualified and inexperienced cadres to municipal management positions, the accumulation of wealth by a few individuals through the tendering system, inadequate revenue because of centralisation of funding and absence of proper systems of collecting revenue by municipalities, which have negatively impaired municipalities. Although this is an empirical research study where both qualitative and quantitative research approaches were followed, there is no evidence of the theoretical and conceptual framework that informs this study. Furthermore, there is no evidence in any article regarding the reliability and validity testing for both qualitative and qualitative approaches which questions the credibility and trustworthiness of the research findings. Meanwhile, Hough (2008) investigated the main causes and theories of revolution in South Africa by analysing recent events pertaining to the ongoing protest actions over service delivery. The author concluded with two basic views: violent protest actions at local level can lead to revolutionary activity and the protest can be contained, but aspects of policy will have to be adapted. Hough (n.d.) has mentioned some incidents of violent protests that have occurred in South Africa over service delivery, especially those accompanied by an overall political motive, which could in fact be viewed as acts of terror. Furthermore, the existence of certain underlying conditions conducive to both political violence and the creation of revolutionary potential is undeniable. While this study's methodology is unclear, the author has highlighted various causes of the violent service delivery protests. However, the majority of the mentioned causes in this article are mostly mentioned in the popular media as evidenced by the domination of the media articles in the reference section of this article. The data in this article can be considered anecdotal, without any basis. There is a serious methodological weakness in this article as the research study is not based on any research design and methodology.

Breakfast et al. (2019) investigated the rationale underpinning violent protests within the Nelson Mandela Bay Municipality by following a qualitative research approach and further provided policy recommendations. This research study was located within the conflict resolution field arguing from a standpoint of a relative deprivation theory. The authors argue that violent service delivery protests cause a security threat because of the lack of stability in affected areas rather than creating an enabling environment for economic development. Breakfast et al. (2019) suggested that there is an intricate interconnection between 'national security' and economic development. These authors suggested that the security cluster, which includes the Defence, Intelligence, Security and Police, needs to develop a 'national security strategy' in order to deal with violent service delivery as a security threat to the stability of the country.

A study conducted by Netswera and Kgalame (2014) analysing the escalation of service delivery protests and ascertaining some of the underlying reasons for the mutual exchange of violent behaviour between citizens and the state revealed interesting developments in the scholarly literature such as the fact that municipalities are regarded as the dumping sites for incompetent officials and this has led to the local officials and politicians being the immediate targets when communities revolt. This conclusion is alluded to by Mpehle (2012), who conducted an empirical study that indicated that a disproportionately high percentage (71\%) of the community members felt that the employment of municipal officials occupying strategic positions was not based on their competency levels, but rather on their political affiliations. This literature study has found that provinces with limited revenue sources, which cannot deliver services effectively and efficiently, political infighting, lack of proper financial and record-keeping skills and corruption are implicated in perpetuating service delivery protests. Another study of interest (Nleya et al. 2011) conducted at five sites located in Cape Town and Pietermaritzburg recognised that the so-called 'service delivery protests' may actually emanate from reasons that extend beyond service delivery. The authors found deep-rooted poverty, lack of income, dire living conditions, the high crime rate and a low level of engagement and community interaction, attendance of community meetings and participation in community organisations to be the factors associated with service delivery protests in Khayelitsha (Nleya 2011).

Some researchers (Bond 2010; Booysen 2009b:21) have directly linked service delivery protests to voiceleness of public communities in meaningful participation in decisionmaking processes, structures and municipal priorities. Mayosi et al. (2012:6) are of the view that a vigorous longterm strategy of programmes to renew trust through community involvement and effective governance could 
alleviate marginalisation of the people. A study by Netswera and Kgalame (2014) analysed the escalation of service delivery protests and ascertained underlying reasons. They concluded that campaigns such as Masakhane to influence public participation in municipalities and payment of services were short-lived. Meanwhile, Mpehle (2012) conducted a study in three provinces (KwaZulu-Natal, Gauteng and North West) where semi-town or tribal authorities were targeted. This exploratory study found that communities were not engaged in decision-making processes, which created a communication gap between the elected and the electorate. A study conducted by Nleya et al. (2011) investigated the origins of protests in South Africa in two cities - Cape Town and Pietermaritzburg - and found that community participation in Cape Town was higher than in Pietermaritzburg. Another study by Nleya (2011) on service delivery and protest in Khayelitsha, a black township in Cape Town, revealed that interest in public affairs and participation in communal meetings were very important variables in the generation of social protests. Beyond the issue of service delivery, the protests echoed 'dysfunctional relationships between citizens and government' (Nemeroff 2005:10). While the protests were often linked to immediate service delivery issues such as lack of water supplies, housing and electricity, it is clear that citizens also wanted to express their dissatisfaction with government's poor consultation and its limited engagement with citizens at the local government level (Mathekga \& Buccus 2006:13). Ngcamu (2014:144) postulates that community participation by departments in municipalities, including eThekwini Municipality, has neglected the constitutional responsibility of consulting and influencing participation of the local communities in municipal governance.

From the current literature study, it is suggested that research findings and conclusions emanating from studies on service delivery protests are based not only on untested perceptions, but also on speculation or hearsay. Some researchers have cited a number of factors, such as revolution or rebellion of the grassroots, unemployment and poverty, lack of houses, corruption and nepotism, as contributing or linked to service delivery protests; however, these are mostly beyond the mandate of municipalities. Nevertheless, poor rendering of basic services to communities and inadequate communication between municipalities and communities are mostly linked to the service delivery protests.

The literature that has been analysed above on the service delivery protests has shown a limited basis, with the authors being silent on their designs and methodologies, and theoretical, conceptual and policy contribution. The following themes emerged from reviewing the secondary data which are mostly reported in the popular media and focussing on the causes of the service delivery protests:

- poor quality of the rendered services, which include water, electricity, housing and sanitation

- inadequate supply and delivery of the municipal services and lack of accountability from councillors
- deployment of the incompetent cadres to the municipal management positions

- higher unemployment and poverty

- commercialisation of the municipal services that have skyrocketed electricity and water prices

- service delivery protests coordinated by unemployed youth who are residing in the informal settlements as well as the civil society groups.

Table 1 presents some dimensions of service delivery protests identified by different scholars.

Table 1 displays common themes that have emerged from the critically reviewed literature on the service delivery protests. A number of researchers have consistently concluded that unfulfilled promises on basic service delivery, such as access to proper housing, have triggered the service delivery protests. The table also shows that poor and inadequate communication channels between government and local communities have exacerbated service delivery protests, mostly in urban areas. Furthermore, some researchers have concluded that local communities are inadequately consulted on government programmes and initiatives, with the majority of them not participating in government projects.

\section{Conclusion}

The literature study has shown there are misconceptions concerning the labelling of public protests as 'service delivery protests' as some studies are not underpinned by any theory; nor do they generate any. It is recommended that future researchers locate protests within particular theoretical frameworks in order to contribute to the body of scholarly knowledge. It is evident from the available literature that most 'service delivery protests' occur in Gauteng and the Eastern Cape provinces, yet a few studies have been conducted in these provinces. An understanding of the protest phenomenon will be enhanced if future researchers conduct scholarly and empirical studies in rural, urban and rural-urban fringe areas of these provinces to determine underlying causes of 'service delivery protests' and dimensions, which are linked to municipalities.

Given that previous studies conducted by some scholars are not systematic, not anecdotal and, mostly, not academic, it is problematic to attribute 'service delivery protests' to municipal employees not performing up to standard. Furthermore, the public has no reliable means to measure or ascertain how good municipal official's competency levels are and how well they are performing. Future researchers need to focus on determining the performance levels of municipal employees and assessing their competency levels using mixed-methods research to ensure that their findings are reliable and valid. Such systematic approaches will assist in developing relationships between service delivery, protests and dimensions of the 'service delivery protests'. Nyar and Wray (2012) argue that service delivery is a complex phenomenon that requires further critical examination and 
TABLE 1: Dominant dimensions and interconnections on service delivery protests.

\section{Author(s)}

Alexander (2010); Hough (2008); Sebugwawo (2011)

Alexander (2010); Atkinson (2007); Bond (2010); Booysen (2009b); Botes et al. (2007); Hough (2008); Netswera and Kgalame (2014); Nleya et al. (2011);

Pithouse (2009); Sebugwawo (2011); Sinwell et al. (2009)

Akinboade et al. (2013); Booysen (2009a,b); Hart (2008); Research Unit of the South African Parliament (RUSAP) (2009); Thompson and Nleya (2010)

Akinboade, O.A., Mokwena, M.P. \& Kinfack, E.C. (2014)

Bond (2010); Booysen (2009a,b); Botes et al. (2007); Akinboade et al. 2014; RUSAP (2009); Thompson and Nleya (2010)

Atkinson (2007); Booysen (2009:130); EISA (2006a,b); Mpehle (2012) RUSAP (2009);

Netswera (2005); Netswera and Kgalame (2014); Thompson and Nleya (2010);

Alexander, Runciman and Ngwane (2013); Mpehle (2012); Akinboade et al. (2013)

Akinboade et al. 2014

Booysen (2009:130); Mpehle (2012); Akinboade et al. 2014

Akinboade et al. 2014

Akinboade et al. 2014

Booysen (2009b); Hart (2008); Marais et al. (2008); RUSAP (2009); Thompson and

Nleya (2010)

RUSAP (2009)

Booysen (2009:130); Nleya et al. (2011); RUSAP (2009)

Hough (2008); Akinboade et al. 2014

Akinboade et al. 2014

Booysen (2009a,b); Friedman (2009); Schlemmer (quoted in EISA 2006a, b)

Hart (2008); Hough (2008); Thompson and Nleya (2010)

Hough (2008)

Hough (2008); Thompson and Nleya (2010)

Nyar and Wray (2012:23); Pithouse (2007); Thompson and Nleya (2010)

Alexander (2010); Mpehle (2012)
Dimensions or interconnections

Develop into a revolution in the country

Frustration of promises (mostly during election periods) not fulfilled on service delivery and unresponsive local government and dissatisfaction with overall poor performance (inefficiencies and ineffectiveness)

Unemployment and poverty

Poor infrastructure

Lack of houses and/or land (those available constructed with flimsier materials)

Rampant corruption, uncaring, self-serving and nepotism (awarding of service tenders; opulent life styles of politicians, incompetent contractors doing shoddy work)

Deployment of ANC cadres who are incompetent

Poor governance

Individual political rivalries/infighting

Inefficient management

Issues of affordable and unfunded mandates

Lack of or poor service delivery (e.g. water, sanitation, electricity and refuse removal)

Maladministration, financial mismanagement, lack of leadership in the municipality

Lack of communication in debriefing local communities and voicelessness of people in decision-making

Personally or politically motivated who did not make it on the ANC candidates list before elections

Inept councillors

Failing to consult with communities, invisible municipal and ward committee members

Crime

Allegations of 'third-force'

Civil society movements

Yielding results from government and being heard by government authorities

Funding, lack of proper financial and record-keeping skills and foreigners occupying RDP houses rigorous and coordinated data collection initiatives. The development of comprehensive, informed and reliable data sources could improve critical reflections on the meanings and consequences of 'service delivery protest' for transformation and development at community level.

To sum up, this literature review study recognises three major limitations in published studies on 'service delivery protests'. Firstly, there is a paucity of studies between 1994 and 2000. Secondly, most studies are narrative analyses of protest events not grounded in any research philosophy, tradition, theory or framework. Lastly, most of the studies are qualitative, with no ways to test the reliability and validity and, consequently, the acceptability of their findings. To address the theoretical, conceptual and methodological shortcomings observed in the previously published scholarly works on service delivery protests, future researchers should conduct case research studies in different provinces, such as the Eastern Cape province (which is mostly rural), which has seen an increase in service delivery protests in 2018 compared to other provinces. A mixed-methods research approach should be followed with the various stakeholders sampled, including traditional leaders, civil society groups, activists, ward councillors, SAPS, municipal officials and the ward committees. The structured questionnaires should be used to test the householders' perceptions about the underlying causes of service delivery protests. In-depth interviews and focused group discussions should be conducted in order to determine new theories, concepts, themes or dimensions and trends.

\section{Acknowledgements Competing interests}

The author has declared that no competing interests exist.

\section{Author's contributions}

B.S.N. wrote this article independently without any assistance.

\section{Ethical considerations}

This article followed all ethical standards for research without direct contact with human or animal subjects.

\section{Funding information}

This research received no specific grant from any funding agency in the public, commercial or not-for-profit sectors.

\section{Data availability statement}

Data sharing is not applicable to this article as no new data were created or analysed in this study.

\section{Disclaimer}

The views and opinions expressed in this article are those of the authors and do not necessarily reflect the official policy or position of any affiliated agency of the authors. 


\section{References}

Akinboade, A.O., Mokwena, M.P. \& Kinfack, E.C., 2013, 'Understanding citizens' participation in service delivery protests in South Africa's Sedibeng distric municipality', International Journal of Social Economics 40(5), 458-478. https:// doi.org/10.1108/03068291311315331

Akinboade, O.A., Mokwena, M.P. \& Kinfack, E.C., 2014, 'Protesting for improved public service delivery in South Africa's Sedibeng District', Social Indicators Research 119(1), 1-23.

Alexander, P., 2010, 'Rebellion of the poor: South Africa's service delivery protests - A preliminary analysis', Review of African Political Economy 37(123), 25-40. https:// preliminary analysis', Review of African
doi.org/10.1080/03056241003637870

Alexander, P., Runciman, C. \& Ngwane, T., 2013, Media briefing-community protests 2004-2013: Some research findings, Social Change Research Unite, University of Johannesburg, Johannesburg.

Alexander, P., Runciman, C., Ngwane, T., Moloto, B., Mokgele, K. \& Van Staden, N., 2018, 'Frequency and turmoil: South Africa's community protests 2005-2017', South African Crime Quarterly 63, 27-42. https://doi.org/10.17159/2413-3108/2018/v0n63a3057

Atkinson, D., 2007, 'Taking to the streets: Has developmental local government failed in South Africa', State of the Nation: South Africa 2007, 53-77.

Beall, J., Gelb, S. \& Hassim, S., 2005, 'Fragile stability: State and society in democratic South Africa', Journal of Southern African Studies 31(4), 681-700. https://doi. South Africa', Journal of Southern
org/10.1080/03057070500370415

Bond, P., 2000, Elite transition: From apartheid to neoliberalism in South Africa, University of Natal Press, Pietermaritzburg.

Bond, P., 2010, 'South Africa's bubble meets boiling urban social protest', Monthly Review 62(2), 17. https://doi.org/10.14452/MR-062-02-2010-06_2

Bond, P. \& Mayekiso, M., 1996, 'Developing resistance, resisting development', Socialist Register: Are there alternatives? 32, 33-61, viewed 09 May 2017, from http://socialistregister.com/index.php/srv/article/view/5668/2565.

Booysen, S., 2009a, 'Beyond the ballot and the brick: Continuous dual repertoires in the politics of attaining service delivery in South Africa', in A. McLennan \&
B. Munslow (eds.), The politics of service delivery pp. 104-136, Wits University B. Munslow (eds.),
Press, Johannesburg.

Booysen, S., 2009b, 'Public participation in democratic South Africa: From popula mobilization to structured co-optation and protest', Politeria 28(1), 1-27.

Botes, L., Lenka, M., Marais, L., Matebesi, Z. \& Sigenu, K., 2007, 'The cauldron of local protests: Reasons, impacts and lessons learned', University of the Free State, Bloemfontein.

Breakfast, N., Bradshaw, G. \& Nomarwayi, T., 2019, 'Violent service delivery protests in post-apartheid South Africa, 1994-2017-a conflict resolution perspective' African Journal of Public Affairs 11(1), 106-126.

Chigwata, T.C., O'Donovan, M. \& Powell, D.M., 2017, Civic protests and local government in South Africa, Working Paper Series No. 2. The Civic Protest Barometer 2, 2007-2016. Dullah Omar Institute, University of the Western Cape, Cape Town.

Economic Empowerment Rating Agency (CityDex), 2009, EMPOWERDEX Service Delivery Index (CityDex), viewed 16 January 2019, http://www.empowerdex. com/Portals/5/docs/Press\%20releases/citydex_report.pdf

EISA, 2006a, Election update South Africa: Local government elections, local government elections, EISA, Johannesburg.

EISA, 2006b, Youth participation in political processes in Southern Africa, viewed 21 May 2017, from www.eisa.org.za/EISA/conferences

Freedom of Expression Institute and Centre for Sociological Research, 2009, National trends around protest action: Mapping social protest action in South Africa, Freedom of Expression Institute and Centre for Sociological Research, Johannesburg.

Friedman, S., 2009, 'People are demanding public service not service delivery', Business Day, July 29.

Hart, G., 2008, 'The provocations of Neo-liberalism: Contesting the nation and liberation after apartheid', Antipode 40(4), 678-705. https://doi.org/10.1111/ j.1467-8330.2008.00629.x

Hough, M., n.d., Violent protest at local government level in South Africa: Revolutionary potential?, University of Pretoria, Pretoria.

Hough, M., 2008, 'Violent protest at local government level in South Africa: Studies 36(1), 1-13, viewed 10 May 2017, from http://www.dpsa.gov.za/dpsa2g/ documents/nlr/lr_policyframework.pdf.

Kotze, J.S. \& Taylor, D., 2010, 'Ke nako: service delivery as a key challenge for the Zuma administration: a developmental local government perspective', Africa Insight 40(3), 198-212. https://doi.org/10.4314/ai.v40i3.64420

Mananga, A., 2012, Unfulfilled promises and their consequences: A reflection on local government performance and the critical issue of poor service delivery in South Africa, Policy brief (AISA) 76(1-8), African Institute of South Africa (AISA), Pretoria.

Marais, L., Matebesi, Z., Mthombeni, M., Botes, L. \& Van Rooyen, D., 2008, 'Municipal unrest in the Free State (South Africa): A new form of social movement?' Politeia 27(2), 55-69.

Matebesi, S. \& Botes, L., 2017, 'Party identification and service delivery protests in the Eastern Cape and Northern Cape, South Africa', African Sociological Review/Revue Africaine de Sociologie 21(2), 81-99.

Matebesi, Z., 2011, 'Qualitative evidence of municipal service delivery protests: Implications for South Africa', 2nd annual conference on qualitative research for policy making, 26th and 27th May, Merlien Institute, Belfast.

Mathekga, R. \& Buccus, I., 2006, 'The challenge of local government structures in South Africa: Securing community participation', Critical Dialogue Public Participation Review 2(1), 11-17.
Mayosi, B.M., Lawn, J.E., Van Niekerk, A., Bradshaw, D., Karim, S.S.A., Coovadia, H.M. \& Lancet South Africa team, 2012, 'Health in South Africa: Changes and challenges since 2009', The Lancet 380(9858), 2029-2043. https://doi.org/10.1016/S01406736(12)61814-5

McLennan, A. \& Munslow, B. (eds.), 2009, The politics of service delivery, University of the Witwatersrand Press, Johannesburg.

Morudu, H.D., 2017, 'Service delivery protests in South African municipalities: An exploration using principal component regression and 2013 data', Cogent Socia Sciences 3(1), 1329106. https://doi.org/10.1080/23311886.2017.1329106

Mpehle, Z., 2012, 'Are service delivery protests justifiable in the democratic South Africa?', Journal of Public Administration 47(1), 213-227.

Muller, M., 2007, 'Parish pump politics: The politics of water supply in South Africa' Progress in Development Studies 7(1), 33-45. https://doi.org/10.1177/146499 Progress in Deve
340600700104

Municipal IQ, 2014, Municipal IQ condemns the use of excessive force in service delivery protests, viewed 22 May 2017, from https://www.municipaliq.co.za/ publications/press/201401291050232363.docx.

Municipal IQ, 2016, Service protests retreat with local elections, viewed 22 May 2017, from https://www.municipaliq.co.za/publications/press/2016092215581 28385.doc.

Municipal IQ, 2019, Service protests retreat with local elections, viewed 16 January 2019, from https://www.municipaliq.co.za/publications/press/2016092215581 28385.doc.

Nemeroff, T., 2005, Probing the protests' in delivery, Institute for Democracy in South Africa-IDASA, Pretoria.

Netswera, F.G., 2005, 'Local government service provision and non-payment within underdeveloped communities of the Johannesburg Unicity: Service protests 2004-2013: Some research findings', Social Change Research Unit: University of Johannesburg: Providers' and Consumers' Perspective, Doctoral thesis, University of Stellenbosch.
ohannesurg:

Netswera, F.G. \& Kgalame, S., 2014, 'The underlying factors behind violent municipal service delivery protests in South Africa', Journal of Public Administration 49(1), 261-273.

Ngcamu, B.S., 2014, 'Responsiveness of Community Participation and Action Support Unit's activities to local communities' needs: A case of eThekwini Municipality', Administratio Publica 22(4), 144-159.

Ngwane, T., 2010, 'Civil society protests in South Africa: The need for a vision of alternatives', paper presented at a Centre for Civil Society (CCS) seminar, Durban, University of KwaZulu Natal, March 9, 2010.

Ngwane, T., n.d., Civil society protests in South Africa: The need for a vision of alternatives, viewed 10 May 2017, from http://archiv.labournet.de/ of alternatives, viewed 10 May 2017, from
internationales/suedafrika/ngwanealternativen.pdf.

Nleya, N., 2011, 'Linking service delivery and protest in South Africa: An exploration of evidence from Khayelitsha', Africanus 41(1), 3-13. Nleya, N., Thompson, L., Tapscott, C., Piper, L. \& Esau, M., 2011, 'Reconsidering the
origins of protest in South Africa: Some lessons from Cape Town and Pietermaritzburg', Africanus 41(1), 14-29.

Nyar, A. \& Wray, C., 2012, 'Understanding protest action: Some data collection challenges for South Africa', Transformation 80, 22-43. https://doi.org/10.1353/ trn.2012.0050

Pithouse, R., 2009, 'Abahlali base Mjondolo and the struggle for the city in Durban, South Africa', Cidades 6(9), 241-270.

Research Unit of the South African Parliament (RUSAP), 2009, Report on the current service delivery protests in South Africa, commissioned by the House Chairperso Committees, Oversight and ICT, August, University of Cape Town, Cape Town.

Sebugwawo, M., 2011, 'Service delivery protests in South Africa: Lessons for municipalities', The Transformer 17(3), 17-18.

Sinwell, L, Kirshner, J., Khumalo, K., Manda, O., Pffaffe, P. \& Phokela, C. et al., 2009, Service delivery protests: Findings from quick response research on four 'hotspots' - Piet Retief, Balfour, Thokoza and Diepsloot, Centre for Sociological Research (CSR), University of Johannesburg, Johannesburg.

South Africa, 1993, Regulation of Gatherings Act 205 of 1993, Government Printer, Pretoria.

South Africa, 1995, Labour Relations Act 55 of 1995, Government Printer, Pretoria.

South Africa, 1996, Constitution of the Republic of South Africa, Government Printer, Pretoria.

South Africa Ministry of Police, 2011, Policy and guidelines: Policing of public protests, Gatherings and Major Events, viewed 10 May 2017, from http://www. policesecretariat.gov.za/downloads/policies/policing_public_protests_2013.pdf.

South Africa, Department of Public Service and Administration, n.d., Labour Relations Policy Framework for the South Africa Public Service.

South Africa Ministry of Police, n.d., SAPS Standing Order (general) No 262 on crowd management during gatherings and demonstrations, viewed 10 May 2017, from
http://protestinfo.org.za/download/saps_standing_orders/Standing-Order-262http://protestinfo.org.za/download/saps_standing_orders/Standing-Ord
Crowd-management-during-gatherings-and-demonstrations-2004.pdf

Steyn, S. \& Van Heerden, M., 2011, 'Public-private partnerships as solutions to service delivery problems', Administratio Publica 19(3), 167-182.

Thompson, L. \& Nleya, N., 2010, 'Passivity or protest? Understanding the dimensions of mobilization on rights to services in Khayelitsha, Cape Town', in V.S.P. Coelho \& B. Von Lieres (eds.), Mobilizing for democracy: citizen action and the politics of public participation, p. 10, Zed, London.

Vally, N., 2009, 'National trends around protest action: Mapping protest action in South Africa', paper presented at development studies seminar, Centre for Sociological Research, University of Johannesburg, Johannesburg, 20th February. 